American Journal of Agricultural and Biological Sciences 3 (3): 566-574, 2008

ISSN 1557-4989

(C) 2008 Science Publications

\title{
A Review on Some Organic Acids Additives as Shelf Life Extenders of Fresh Beef Cuts
}

\author{
Mohamed B. Jamilah, K.A. Abbas and R. Abdul Rahman \\ Department of Food Technology, Faculty of Food Science and Technology, \\ University Putra Malaysia (UPM), Selangor, Malaysia
}

\begin{abstract}
This study was aiming to present some approaches by which the shelf life of fresh beef cuts was extended. These approaches were based on using organic acids. Therefore the work was started with highlighting the deterioration of some quality attributes due to spoilage and pathogenic microorganisms. These attributes included colour, flavour and lipid oxidation changes. In a given holding temperature, the deterioration are controlled by three major factors, they are $\mathrm{pH}$, water activity and microbial growth. The four organic acids approaches (citric, lactic, acetic and tartaric) were presented as fresh beef shelf life extenders due to their abilities to decrease the $\mathrm{pH}$ and antimicrobial effects. The pros and cons of these approaches as well as the latest published researches were stressed at the end of this review. This information helps the researchers and gives them the motivation to develop new superior approach.
\end{abstract}

Key words: Beef cuts, shelf life extenders, organic acids

\section{INTRODUCTION}

Fresh beef, as a high-energy type of food is considered to be the food of choice due largely to its nutritional value ${ }^{[1]}$. Fresh beef is rich in vitamins and minerals and provides an important source of high quality protein. It has a short shelf life of one day or less at ambient temperature $\left(15-30^{\circ} \mathrm{C}\right)$ and a few days at refrigerated temperature $\left(0-10^{\circ} \mathrm{C}\right)$ due to microbial spoilage of both pathogenic and non-pathogenic ${ }^{[2]}$ and/or lipid oxidation ${ }^{[3-5]}$. The maximum shelf life of fresh beef depends on several factors such as $\mathrm{pH}$, water activity, microbial growth and temperature ${ }^{[6]}$.

Fresh beef has unique biological and chemical properties and its nutrients composition represents an optimum medium for microbial growth. It undergoes deterioration progressively from slaughter until consumption. The shortened shelf-life is due to microbial growth and/or rancidity development which is strongly influenced by initial beef quality, package parameters and storage conditions ${ }^{[7]}$. Microbial growth is the most important factor in spoilage of fresh beef and this is followed by colour deterioration. Different types of spoilage and pathogenic microorganisms may be introduced into and on the surface of fresh beef during slaughtering and processing, which causes rapid spoilage, great loss of valuable protein and also affect human health.
The shelf life represents the useful storage time of food product. Beyond this period, changes in smell, colour, taste, texture or appearance make the product unacceptable. Several factors influence the shelf life of fresh beef such as temperature, $\mathrm{pH}$, oxygen, pressure and light. Oxidation of beef to metmyoglobin is essentially affected by myoglobin oxidation rate, oxygen availability and reducing capacity of the muscle $^{[8]}$. The rate of beef discolouration is more influence by factors such as autoxidation of myoglobin and oxygen consumption ${ }^{[9]}$.

Since fresh beef spoilage results from the activity of mixed populations of microorganisms, the time of spoilage and signs of spoilage depend on its type, type and number of microorganisms involved and storage temperature. Marta et al. ${ }^{[10]}$ reported that Enterobacteriaceae, considered to be hygienic indicators, were found to be less than $10 \mathrm{cfu} \mathrm{g}^{-1}$ at the end of the dry-cured ham. The essential purpose of decontamination is extension of shelf life by reduction of the initial bacterial load ${ }^{[11]}$. The reduction of microbial load, maintaining low storage temperature and packaging are the most effective means to extend the shelf life of fresh beef.

This research work has been devoted to encompass the scattered published articles of varieties of relevant journals focusing on approaches for extending the shelf life of fresh beef cuts using organic acids. But it is

Corresponding Author: Kassim A. Abbas, Department of Food Technology, Faculty of Food Science and Technology, University Putra Malaysia (UPM), Selangor, Malaysia Tel: +60389418534 Fax: 603-89423552 
notable to mention here that, still there is a lack in the information available in the literature in this regard. Therefore this review will help the researchers to develop a superior approach and make further research work. In the light of above, this research paper has been justified.

\section{SOME ATTRIBUTES OF QUALITY DETERIORATION}

pH of fresh beef: The $\mathrm{pH}$ value of beef varies from 4.8-7.2 depending on the glycolytic potential at the time of slaughter but the normal variation is of $\mathrm{pH}$ 5.4-6.0. Fresh beef quality is highly determined by the muscle $\mathrm{pH}$ and its change in time, which in turn is strongly dependent on pre-slaughter conditions (stress), imposed on the animals ${ }^{[12]}$. Stress experienced by animal before slaughter cause glycogen reserves to be depletion resulting in higher ultimate $\mathrm{pH}$. The $\mathrm{pH}$ is also an important determinant of microbial growth and the high $\mathrm{pH}$ beef has a high spoilage potential and a short shelf life ${ }^{[13]}$. Rathina et al. ${ }^{[14]}$ found that the $\mathrm{pH}$ of beef decreased from the initial ( $2 \mathrm{~h}$ postmortem) value of about 6.5-5.9 and from 5.6-5.5 at $24 \mathrm{~h}$ for direct and delayed chilled muscles, respectively. Mottram and Madruga $^{[15]}$ found that the higher ultimate $\mathrm{pH}$ in meat from grass-fed animals might favor the formation of thiazoles and thiophenones because of the availability of amino acid degradation products while decreasing other sulfur volatiles that favor lower $\mathrm{pH}$ (furanthiols, mercaptokin, aliphatic sulfides and thiopenes: breakdown products of cysteine. As $\mathrm{pH}$ increases in meat, the proteins have increased water binding properties. Miller ${ }^{[16]}$ observed that in case of fresh meat with high $\mathrm{pH}$ meat fewer water-soluble proteins were lost during cooking.

Walker and Betts ${ }^{[17]}$ reported that ultimate $\mathrm{pH}$ of meat was significant for its resistance to spoilage because most bacteria grow optimally at about $\mathrm{pH} 7$ and not well below $\mathrm{pH} 4$ or above $\mathrm{pH} 9$. Abril et al. ${ }^{[18]}$ concluded that the low $\mathrm{pH}$ also affects beef colour by promoting oxidation of the haem pigments from the purple or red myoglobin $(\mathrm{Mb})$ and oxymyoglobin $\left(\mathrm{MbO}_{2}\right)$ to the brown met myoglobin (met $\mathrm{Mb}$ ).

Water activity: Water activity $\left(\mathrm{A}_{\mathrm{w}}\right)$ is an important factor in the preservation and quality of meat. It is defined as a measure of how much of the water in a product is free referring to the water that is not chemically or physically bound ${ }^{[19]}$. However Pham ${ }^{[20]}$ defined that water activity is the availability of water for deteriorative changes or microbial growth. The main variables that affect microbial growth are the surface temperature and surface water activity. Microbial growth on the surface of foods is mainly controlled by water activity, temperature and $\mathrm{pH}^{[21]}$. The surface temperature and water activity are the results of the balances of heat and water transfer which take place both inside the product and at the air/product interface $^{[22]}$. When water evaporation was considered by taking the energy balance at the product surface, the water flow was proportional to the difference in partial pressure of water vapour between product surface and air and product surface water activity appeared explicitly within the boundary conditions of the coupled heat and mass transfer equations.

Spoilage and pathogenic microorganisms: Fresh beef becomes contaminated with spoilage as well as pathogens during the slaughter process when faecal materials come into contact with the carcass producing surface contamination on the carcass, which may be transported into the interior of the meat tissues ${ }^{[23]}$. These microorganisms have serious effect on meat safety issues resulting in immediate consumer health problems. Pathogenic bacteria that associated with fresh beef were Escherichia coli O157: H7, Listeria monocytogenes, E. coli O157: H7, Salmonella, while the Gram-positive L. monocytogenes which can be transfer to the meat that exposed to recontamination particularly during slicing and packaging. Schylter et al. ${ }^{[24]}$ found that application of antimicrobials such as sodium lactate and diacetate were effective at inhibiting relatively high levels of pathogens L. monocytogenes in study carried using turkey slurries. These authors found that lactate with 0.1 or $0.3 \%$ diacetate was substantially more effective at inhibiting L. monocytogenes growth than diacetate alone. They concluded that diacetate and lactate appeared to be synergistic resulting in greater antimicrobial action than can be achieved with either additive by itself. However Wicklund et al. ${ }^{[25]}$ found that addition of both lactate and diacetate to a salt/phosphate enhancement solution resulted in the greatest reduction of $E$. coli $\mathrm{K} 12$, followed by lactate. Many researchers ${ }^{[26-29]}$ suggested that to improve the microbiological quality of the meat by application of anti-microbial which result in:

- Reduction of contamination on the raw product (live animal)

- Minimizing the access of microorganisms to the product (carcass or meat)

- Reduction of the contamination that has gained access to the product

- Inactivate microorganisms on the product without cross-contamination 
- Prevent or control growth of microorganisms which have gained access to the meat and have not been inactivated.

Lipid oxidation and its products: Lipid oxidation reactions can lead to rancidity, loss of nutritional value from the destruction of vitamins (A, D and E) and essential fatty acids and the possible formation of toxic compounds and coloured products ${ }^{[30]}$. The important lipids involved in oxidation are the polyunsaturated fatty acid moieties, oleic, linoleic and linolenic acids which are susceptible to peroxidative damage in the presence of oxygen free radicals ${ }^{[31]}$. Consequently the rate of oxygen free radical formation plays an important role in the process of lipid peroxidation. The rate of oxidation of these fatty acids increases with the degree of unsaturation.

Lipid oxidation in fresh beef initiated at the membrane level in the intracellular phospholipid fractions. It can be prevented effectively using antioxidants such as carnosine ${ }^{[32-35]}$ and carnitine ${ }^{[36]}$. $\mathrm{O}^{\prime}$ Grady et al.$^{[37]}$ approved that using combination of high $\mathrm{O}_{2}$ atmospheres and natural antioxidants could effectively extend the shelf life of fresh beef by not only inhibiting lipid oxidation, but also kept myoglobin $(\mathrm{Mb})$ in its oxygenated state and consequently extending meat shelf since the latter showed a close similarity in its progression compared to lipid oxidation ${ }^{[38]}$.

The oxidation of lipids leading to rancidity is one of the most important changes during food storage and production $^{[39]}$. Oxidation of lipids gives products that may change the colour, aroma, flavour, texture and even the nutritive value of the food ${ }^{[40]}$. Lipid oxidation is associated with a characteristic rancid unpalatable odor and flavour of oils. Oxidised flavours are concerned with the changes that result from the reaction with atmospheric oxygen i.e., oxidative rancidity or by hydrolytic reaction catalyzed by lipases from food or from microorganisms.

The oxidative rancidity process cannot occur in the absence of oxygen. Thus, vacuum packaging provides longer shelf life by excluding the oxygen from the packaging environment. Hydrolytic rancidity by enzymes may occur in beef or its fats where there is microbial growth. Crushing or macerating tissue of beef starts off lipolysis, as a result of lipolytic enzymes, lipases released, which act on lipids to release the free fatty acids as shown in Fig. 1.

The free fatty acids or and the triglycerides are capable of being oxidized by autoxidation or lipoxygenases. Pearson et al. ${ }^{[41]}$ reported that the development of off-flavours or odors (rancidity) was a serious problem during storage of beef products.

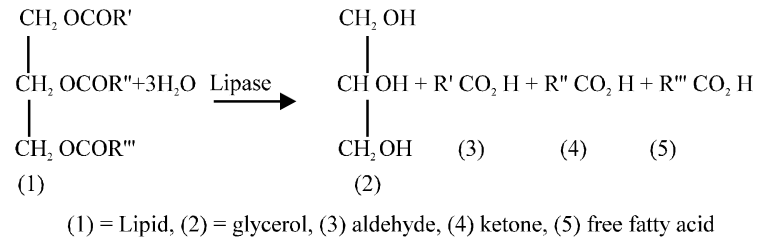

Fig. 1: Reaction of lipase with fatty acids in beef

Oxidative rancidity of muscle systems begins shortly after slaughter and involves the production of a complex mixture of aldehydes, ketones and alcohols ${ }^{[5]}$ which continue to increase in intensity until beef product becomes unacceptable to consumers ${ }^{[42]}$. However, Young et al. ${ }^{[19]}$ demonstrated that all aldehydes and ketones were not associated with rancid odor but saturated aldehydes, like hexanal and have classically been associated with development of rancidity in lamb meat. The initial step in lipid oxidation was the generation of highly transient hydroperoxides that further degrade into malonaldehyde (MA) and other secondary compounds.

Numerous factors affect lipid oxidation including light, oxygen concentration, temperature, presence of anti- and pro- oxidants, degree of unsaturated fatty acids and the presence of enzymes ${ }^{[43]}$, fatty acid composition and the balance between prooxidants and antioxidants factors ${ }^{[5]}$ were published earlier. When beef including its fat, is minced or chopped, as in processing of many beef products, the cellular tissue is more or less broken down so that the lipids are exposed to the chemical attack from which they are previously protected. At the same time the muscle tissue is also broken down and its constituents are made more readily available for chemical or microbiological interactions. Chemical changes including rancidity are more rapid in comminuted beef and beef products.

Changes in colour due to formation of metmyoglobin: metmyoglobin (MetMb) formation in is one of the factors that affect the colour of fresh beef particularly the packaged meat. Faustman and Cassens ${ }^{[44]}$ reported that to minimize formation of MetMb in fresh beef, oxygen $\left(\mathrm{O}_{2}\right)$ must be either totally excluded from the packaging environment or injected at saturating levels. However, Djamel et al. ${ }^{[45]}$ suggested that in order to maintain the red pigment in its oxygenated form $\left(\mathrm{MbO}_{2}\right)$, high $\mathrm{O}_{2}$ atmospheres have to be used in this case. Those authors also reported that care should be taken when $\mathrm{O}_{2}$ is used since high levels of it can also promote lipid oxidation leading to ultimately MetMb accumulation. 
Change in beef flavour during storage: There is a gradual loss of flavour during storage of beef and this may occur even in the frozen condition due to the slow loss of highly volatile substances ${ }^{[46]}$. Undesirable odor and taste may arise during storage of beef because of microbial growth and chemical deterioration on the surface. The lipases of microorganisms which attack fat, splitting of fatty acids with more or less unpleasant consequences according to their nature. The nature of the off-odor depends on the types of microorganisms growing and those will be determined by such factors as the temperature of storage and the nature of product (fresh, cured and comminuted). It is generally accepted that autoxidation of membrane of phospholipids is largely responsible for the development of off-odour ${ }^{[47]}$. However, Calkins and Hodgen ${ }^{[48]}$ reported that diets high in polyunsaturated fatty acids may be contributing to the appearance of off-flavors in fresh beef muscles.

\section{ORGANIC ACIDS AS PRESERVATIVES TO PROLONG THE SHELF LIFE OF BEEF}

Some of the more widely researched antimicrobials include organic acids, such as lactic, acetic and citric acid, these acids also can enhance or contribute to the flavour of acidified or fermented food, such as sausage, cheese and pickles. The use of any antimicrobial depends on several factors, such as desired effect, legal limits of use and effect on food.

The effectiveness of organic acids as antimicrobials differ widely based on concentration, $\mathrm{pH}$, molarity and the concentration of the nondissociated form $^{[49]}$. Currently, organic acids are allowed to be used at $<2.5 \%$ of solution for pre- chilled carcass washing. Lactic acid is also allowed to be used at $5 \%$ of solution as a pre and post-chilled wash for beef carcasses. The application of food acids such as citric, lactic and acetic (organic acids rinses) as a single or in combination have been shown to be effective in reducing both spoilage and pathogenic microorganisms ${ }^{[50]}$. Researchers ${ }^{[51]}$ treated fresh sheep/goat meat using spray washed method with $2 \%$ lactic acid and $1.5 \%$ acetic $+1.5 \%$ propionic acid combination decreased viable count (TVC) of the treated meat samples by about 0.52 and $1.16 \log$ units with marginal changes in colour and odour. The authors found that spoilage organisms were highly sensitive to acid combination treatment as compared to lactic acid alone. The shelf-life of acid and acid combination treated samples was increased to 8 and 11 days as against 3 days in untreated samples.

A recent research by Eleftherios et al. ${ }^{[52]}$ in using the salts of some organic acids (sodium lactate (SL) in concentrations of $(2,3$ or $4 \%)$, sodium acetate (SA) in a concentration of $(0.5 \%)$ and potassium sorbate (PS) in a concentration of $(0.15 \%)$ combination) have shown that lactate and acetate and to a less extent sorbate exhibited antimicrobial activity. However, the antimicrobial activity was observed with the increase of their concentration in the growth medium. Enhanced inhibition was also observed when the salt combination of two or three salts was used $(2 \% \mathrm{SL}+0.5 \% \mathrm{SA}$ or $0.15 \%$ PS, $2-4 \%$ SL + 0.5\% SA + 0.15\% PS).

Since microbial growth in beef and its products occurs primarily at the surface, attempts have been made to delay spoilage by using an organic acid spray or dips as antimicrobial agents ${ }^{[53]}$. The mode of action of organic acids is that the undissociated acid penetrate the cell of microorganisms by means of diffusion and then dissociates and acidify the cell interior, thus interfering with cellular metabolism or decreasing the biological activity as a result of $\mathrm{pH}$ changes of the cell's environments ${ }^{[54]}$.

In general, bacteria prefer a $\mathrm{pH}$ near neutrality $(\mathrm{pH}$ 6.5-7.5). Bacteria primarily spoil beef at $\mathrm{pH}$ range of 6.0-6.5. One effective means of limiting microbial growth is to increase the acidity of beef, thereby creating an unfavorable environment for the growth. The lower $\mathrm{pH}$ disturbs the homeostasis of the bacterial cells, including pathogens and spoilage bacteria ${ }^{[55]}$.

Some of the common approaches using organic acids are summarized as below:

Citric acid: Citric acid, 2- hydroxy-1, 2, 3-propane tricarboxylic acid is a white powder extracted from the juice of citrus and other acidic fruits such as lemons, limes, pineapples and gooseberries. It is also produced by the fermentation of glucose. Citric acid is highly soluble in water and primarily insoluble in fat. Citric acid was investigated for its effect on inhibition of bacteria, yeast and molds and was shown to be inhibitorier than lactic acid and acetic acid ${ }^{[56]}$. It was used in acidified beef, to reduce the risk of bacterial contamination and to improve the texture ${ }^{[57]}$. This acid exhibits both bactericidal and antistatic effects against L. monocytogenes ${ }^{[58]}$. The antibacterial activity of citric acid is dependent on $\mathrm{pH}$, concentration and anion effects $^{[59]}$.

Acetic acid: Acetic acid is a mono carboxylic acid with a pungent odor and taste. It is commonly known as vinegar which has antimicrobial capabilities due to its ability to lower the $\mathrm{pH}$ and cause instability of bacterial cell membranes ${ }^{[60]}$. Acetic acid has been shown to be effective against E. coli O157: H7, reducing this pathogens by $0.1 \log _{10}$ colony forming 
unit (cfu $\left.\mathrm{g}^{-1}\right)^{[61,62]}$. Also it reduced Salmonella typhimurium by $0.73 \log \mathrm{cfu} \mathrm{cm}^{-2}$ on carcass tissue surfaces ${ }^{[63,64]}$ but colour deterioration of whole muscle cut surfaces have been reported already ${ }^{[65]}$. Concentration of $3 \%$ acetic acid was quite effective in reducing counts of Enterobacteriaceae in vacuum packaged beef stored for 6 weeks at $2.4^{\circ} \mathrm{C}$. A level of $0.2-0.5 \%$ acetic acid reduced Enterobacteriaceae counts by $2.24 \mathrm{log}$. Acetic acid is generally regarded as safe for miscellaneous and general-purpose usage.

Lactic acid: Lactic acid, which is a weak acid, may occur in both a dissociated and an undissociated form depending on the $\mathrm{pH}$. It is the undissociated form of lactic acid that inhibits bacterial growth. The inhibitory capacity of this acid lies in its reduction of $\mathrm{pH}$ to levels below which bacteria cannot initiate growth. Lactic acid is an excellent inhibitor of spore forming bacteria at $\mathrm{pH}$ 5.0. Anderson and Marshall ${ }^{[66]}$ found that the combination of lactic and acetic acid in concentration of $100 \%$ was most effective in reducing spoilage bacteria. Dubal et al. ${ }^{[51]}$ reported that when goat or sheep meat was spray-washed with $2 \%$ lactic acid and stored at refrigeration temperature of $5-7^{\circ} \mathrm{C}$, the shelf-life of acid treated samples was increased to 8 and 11 days as against 3 days in untreated samples and complete spoilage changes with greenish discolouration and putrid odour were noticed in untreated samples on 6th day with corresponding increases in total plate counts to $7.32 \pm 0.28,6.93 \pm 0.73$ and $7.55 \pm 0.76 \mathrm{log} \mathrm{cfu} \mathrm{g}^{-1}$. the salts of this acid such as sodium lactate has been used for several years in the field of meat sciences due to its ability to increase flavour, shelf-life and the microbiological safety of these products. Koos ${ }^{[67]}$ reported that the anti-microbial effects of lactates were due to their ability to lower water activity and to the inhibitory effects of the lactate ion. However Rosiminini et al. ${ }^{[68]}$ successfully used the sodium lactate in extending the shelf-life of cooked ham by reducing psychrotroph, faecal streptococci and Enterobacteriaceae counts and the formation of ropy slime. Lactates play another important role in inhibiting the growth of foodborne pathogens such as E. coli O157: H7, B. cereus, Listeria monocytogenes, Clostridium botulinum, Staphylococcus aureus, $Y$. enterocolitica ${ }^{[69-74]}$. Recently, Ana et al. ${ }^{[75]}$ studied the antimicrobial effects of potassium and sodium lactates in order to improve the preservation effect of blood sausage and have concluded that the shelf life of the product can be extended to 15 days.

Tartaric acid: Tartaric Acid can be manufactured synthetically or recovered from natural sources. Natural or L+ tartaric acid is used in food industry. Tartaric acid, the most soluble of the solid acidulants, has a strong tart taste that enhances grape-like flavour. It is a white, crystalline powder with a strong fruit acid flavour, approximately $10 \%$ stronger than citric acid according to an industry source. It is highly soluble in water and Tartaric acid completely inhibited the growth of $E$. coli $\mathrm{O} 157$ : $\mathrm{H} 7$ when it was used in combination with silver ions at $1.0 \mathrm{ppm}$ in concentration of $0.1 \%^{[76]}$.

\section{REGULATORY STATUS OF FOOD GRADE ORGANIC ACIDS}

Organic acids are GRAS and are listed in FSIS regulations for use as an acidifier (which may have an antimicrobial effect) in various meat products at a level which is sufficient for purpose at a concentration of up to $2.5 \%$ of a solution without labeling ${ }^{[77,78]}$. FSIS has no objection to the use of organic acids on conveyor belts on continuous basis. However, the process should not result in the organic acids having a lasting technical effect on meat. However, the FSIS-USDA has currently approved the use of solutions of acetic, lactic and citric acids at concentrations of $1.5-2.5 \%{ }^{[79]}$. There have been several studies investigating the use of organic acids as sanitizing solutions to improve shelf-life and safety of fresh meat ${ }^{[2,64,78,80]}$. In general, organic acid have been effective (1-3 log reductions in $\log$ mean bacterial counts) in reducing bacterial populations and presence of pathogens on carcasses $^{[2,81]}$.

\section{CONCLUSIONS}

The shelf life of fresh beef is highly depended on many factors such as $\mathrm{pH}$, water activity, microbial contamination including pathogens, lipid oxidation and colour changes which if they controlled, potential shelf life can be achieved. One of the ways to extend the shelf life of fresh beef is through using of organic acids such as citric acid, acetic, lactic and tartaric acids in individually or in combination which can result in effective shelf life extension of fresh beef.

\section{REFERENCES}

1. Rule, C.D., D.M. MacNeil and E.R. Short, 1997. Influence of sire growth potential, time on feed and growing-finishing strategy on cholesterol and fatty acids of the ground carcass and longissimus dorsi muscle of beef steers. J. Anim. Sci., 75: 1525-1533.

2. Dickson, J.S. and M.E. Anderson, 1992. Microbiological decontamination of food animal carcasses by washing and sanitizing system. J. Food Sci., 48: 156-163. 
3. Houben, J.H., A. van Dijk, G. Eikelenboom and A.H. Hoving-Bolink, 2000. Effect of dietary vitamin E supplementation, fat level and packaging on colour stability and lipid oxidation in minced beef. J. Meat Sci., 55: 331-336.

4. Shahidi, F., 1994. Assessment of Lipid Oxidation and off-Flavor Development in Meat and Meat Products. In: Flavor of Meat and Meat Products, Shahidi, F. (Ed.). Blackie Academic and Professional, London, UK, pp: 53.

5. Morrissey, A.P., P.J.A. Sheehy, K.J.P. Galvin, P.J.K. Kerry and D.J. Buckley, 1998. Lipid stability in meat and meat products. J. Meat Sci., 49: 73-86.

6. Farber, J.M., 1991. Microbial aspects of modified atmosphere-packaging technology a review. J. Food Prot., 54: 58-70.

7. Zhao, Y., J.H., Wells and K.W. McMillin, 1994. Applications of dynamic modified atmosphere packaging systems for fresh red meats: Review. J. Muscle Foods, 5: 299-328.

8. Catherine, E., M. Renerre and R. Labas, 1989. Metmyoglobin reductase activity in bovine muscle. J. Meat Sci., 27: 161-172.

9. Renerre, M. and R. Labas, 1987. Biochemical factors influencing meat myoglobin formation in beef muscles. J. Meat Sci., 19: 151-165.

10. Marta, G., A. Diana and A. Iciar, 2003. Comparison of modified atmosphere packaging and vacuum packaging for long period storage of dry-cured ham: effects on colour, texture and microbiological quality. J. Meat Sci., 67: 57-63.

11. Dorsa, W.J., 1997. New and established carcass decontamination procedure commonly used in the beef processing industry. J. Food Prot., 60: 1146-1151.

12. Tarrant, P.V. and D. Lister, 1989. Muscles Metabolisms and Animal Physiology in Dark Cutting Conditions. In: Dark Cutting in Cattle and Sheep, Fabiansson, S.U., W.R. Shorthose and R.D. Warner (Ed.). Australian Workshop, Sydney, pp: 8-25.

13. Newton, K.G. and C.O. Gill, 1981. The microbiology of Dark, firm and dry fresh meats. A review. J. Meat Sci., 5: 223-232.

14. Rathina Raj, K., R. Jagannatha Rao, D. Narasimha Rao and N.S. Mahendrakar, 2000. Influence of direct and delayed chilling of excised female buffalo muscles on their textural quality. J. Meat Sci., 56: 95-99.

15. Mottram, D.S. and M.S. Madruga, 1994. Important Sulfur Containing Aroma Volatiles in Meat. In: Sulfur Compounds in Foods, Mussinan, C.J. and M.E. Keelan, (Eds.). ACS symposium series, American Chemical Society, Washington, DC, 564: 180-187.
16. Miller, R.K., 2001. Beef flavor: A white paper, National Cattlemens' Beef Association, Centennial, CO.

17. Walker, S.J. and G. Betts, 2000. Factors Affecting the Microflora of Chilled Foods. In: Chilled Foods, Stringer, M. and C. Dennis, (Eds.). Woodhead Publishing, London, pp:157-178.

18. Abril, M., M.M. Campo, A. Onenc, C. Saňudo, P. Albert and A.I. Negueruela, 2002. Beef colour evolution as a function of ultimate $\mathrm{pH}$. J. Meat Sci., 58: 69-78.

19. Young, O.A., D.A. Frost, J. West and T.J. Braggins, 2001. Common Tests for Meat Products. In: Meat Science and Applications, Hui, Y.H., W.K. Nip, R.W. Rogers and O.A. Young (Eds.). Marcel Decker, New York, pp: 115-116.

20. Pham, Q.T., 2001. Modelling Thermal Process: Cooling and Freezing. In: Food process modelling, Tijskens, L.M.M., M.L.A.T.A. Hertog and B.M. Nicolaï (Eds.). Woodhead Publishing Limited, Cambridge, pp: 312-339.

21. Ross, T., 1999. Predictive microbiology model in the meat industry. Meat and Livestock Australia, Sydney.

22. Lebert, I., P. Baucour, A. Lebert and J.D. Daudin, 2005. Assessment of bacterial growth on the surface of meat under common processing conditions by combining biological and physical models. J. Food Eng., 68: 89-98.

23. Davis, J.R., J.K. Apple, D.H. Hellwig, E.B. Kegley and F.W. Pohlman, 2002. The effects of feeding broiler litter on microbial contamination of beef carcasses. J. Bioresour. Technol., 84: 191-196.

24. Schylter, J.H., K.A. Glass, J. Loeffelholz, A.J. Degnan and J.B. Luchansky, 1993. The effects of diacetate with nitrite, lactate, or pediocin on the viability of Listeria monocytogenes in turkey slurries. Int. J. Food Microbiol., 19: 271-281.

25. Wicklund, S.E., A.J. Stetzer, E.M. Tucker, C.L. Nicolalde and M.S. Brewer, 2005. Microbiological characteristics of enhancement solutions. J. Food Sci., 70: 296-300.

26. Juneja V.K. and J.N. Sofos, 2001. In: Control of Foodborne Microorganisms, Juneja V.K. and J.N. Sofos, (Eds.). Marcel Dekker, Inc., New York, NY, pp: 535-536.

27. Sofos, J.N., 1994. Microbial Growth and its Control in Meat, Poultry and Fish. In: Quality Attributes and their Measurement in Meat, Poultry and Fish Products, Pearson, A.M. and T.R. Dutson (Eds.). Blackie Academic and Professional, Glasgow, UK, pp: 359-403. 
28. Sofos, J.N., 2002. Approaches to Pre-Harvest Food Safety Assurance. In: Food Safety Assurance and Veterinary Public Health, Vol. 1, Food Safety Assurance in the Pre-Harvest Phase, Smulders, F.J.M. and J.D. Collins, (Eds.), Wageningen Academic Publishers, Wageningen the Netherlands, pp: 23-48.

29. Stopforth, J.D. and J.N. Sofos, 2006. Recent Advances in Pre- and Post-Slaughter Intervention Strategies for Control of Meat Contamination. In: Advances in Microbial Food Safety, Juneja, V.J., J.P. Cherry and M.H. Tunick (Eds.). ACS Symposium 931. Recent advances in intervention strategies to improve food safety. American Chemical Society, Oxford University Press, Washington, D.C., pp: 66-86.

30. Thomas, J.M., 1995. The role of free radicals and antioxidants: how do we know that they are working? J. Crit. Rev. Food Sci. Nutr., 35: 21-39.

31. Halliwell, B., 1992. Reactive oxygen species and the central nervous system. J. Neurochem., 59: 1609-1623.

32. Decker, E.A. and A.D. Crum, 1991. Inhibition of oxidative rancidity in salted ground pork by carnosine. J. Food Sci., 56: 1179-1181.

33. Zhou, S. and A.A. Decker, 1999. Ability of carnosine and other skeletal muscle components to quench unsaturated aldehydic lipid oxidation products. J. Agric. Food Chem., 47: 51-55.

34. Sánchez-Escalante, A., D. Djenane, G. Torrescano, J.A. Beltrán and P. Roncalés, 2001. The effects of ascorbic acid, taurine, carnosine and rosemary powder on color and lipid stability of beef patties packaged in modified atmosphere. J. Meat Sci., 58: 421-429.

35. Sánchez-Escalante, D., Djenane, G. Torrescano, B. Gimenez, J.A. Beltrán and P. Roncalés, 2003. Evaluation of the antioxidant ability of hydrazinepurified and untreated commercial carnosine in beef patties. J. Meat Sci., 64: 59-67.

36. Djenane, A. Sánchez-Escalante, J.A. Beltrán and P. Roncalés, 2003. Extension of the shelf life of beef steaks packaged in a modified atmosphere by treatment with rosemary and displayed under UVfree lighting. J. Meat Sci., 64: 417-426.

37. O'Grady, M.N., F.J. Monahan, R.M. Burke and P. Allen, 2000. The effect of oxygen level and exogenous alpha-tocopherol on the oxidative stability of minced beef in modified atmosphere packs. J. Meat Sci., 55: 39-45.

38. Djenane, D., A. Sánchez-Escalante, J.A. Beltrán and P. Roncalés, 2001. Extension of the retail display life of fresh beef packaged in modified atmosphere by varying lighting conditions. J. Food Sci., 66: 181-186.
39. Rondinini, G., M. Maifreni and M. Marino, 1996. Application of sodium lactate to preservation of cooked ham. Ingegneria Alimentare le Conserve Animali, 12: 9-15.

40. Fernaňdez, J., J.A. Pérez-Álvarez and J.A. Fernández-López, 1997. Thiobarbituric acid test for monitoring lipid oxidation in meat. J. Food Chem., 59: 345-353.

41. Pearson, M.A., D.J. Love and F.D. Shorland, 1989. Warmed-over-flavor in meat. Adv. Food Res., 23: 1-74.

42. Gray, J.I., E.A. Gomaa and D.J. Buckley, 1996. Oxidative quality and shelf life of meats. J. Meat Sci., 43: 111-123.

43. Skibsted, L.H., A. Mikkelsen and G. Bertelsen, 1998. Lipid-Derived Off-Flavour in Meat. In: Flavour of Meat, Meat Products and Seafoods, Shahidi, F. (Ed.). Blackie Academic and Professional, London, UK., pp: 217-248.

44. Faustman, C. and R.G. Cassens, 1990. The biochemical basis for discoloration in fresh meat: A review. J. Muscle Foods, 1: 217-243.

45. Djamel, D., M. Luis, S. Armida, A. José and R. Pedro, 2003. Antioxidant effect of carnosine and carnitine in fresh beef steaks stored under modified atmosphere. J. Food Chem., 85: 453-459.

46. Lawrie, R.A. 1991. Undesirable Odor and Taste. In Meat Science, Lawrie, R. (Ed.). Woodhead Publishing, Cambridge, pp: 219-230.

47. Angelo, St. A.J., J.R. Vercellotti, M.G. Legendre, C.H. Vinett, J.W. Kuan, C. James and H.P. Dupuy, 1987. Chemical and instrumental analyses of wormed-over flavor in beef. J. Food Sci., 52: 1163-1168.

48. Calkins C.R. and J.M. Hodgen, 2007. A fresh look at meat flavor. J. Meat Sci., 77: 63-80.

49. Beth, A., C. Mark and Z. Zuoxing, 2004a. An overview of antimicrobial ingredients. J. Food Safety 10: 24-25.

50. Dorsa, W.J., C.N. Cutter and G.R. Iragusa, 1997. Bacterial profile of ground beef made from carcass tissue experimentally contaminated with pathogenic and spoilage bacteria before being washed with hot water, alkaline solution, or organic acids and then stored at 4 or $12^{\circ} \mathrm{C}$. J. Food Prot., 6: 1109-1118.

51. Dubal, B.Z., M.A. Paturkar, S.V. Waskar, J.R. Zende, C. Latha, B.D. Rawool and C. Kadam, 2003. Effect of food grade acids on inoculated $S$. aureus, L. monocytogenes, E. coli and $S$. Typhimurium in sheep/goat meat stored at refrigerated temperature. J. Meat Sci., 51: 142-147. 
52. Eleftherios H. Drosinos, Marios Mataragas, Aikaterini Kampani, Dimitrios Kritikos and Ioannis Metaxopoulos, 2006. Inhibitory effect of organic acid salts on spoilage flora in culture medium and cured cooked meat products under commercial manufacturing conditions. J. Meat Sci., 73: 75-81.

53. Siragusa, G.A. and J.S. Dickson, 1992. Inhibition of Listeria monocytogenes on beef tissue by application of organic acids immobilized in calcium alginate gel. J. Food Sci., 57: 293-296.

54. Cherrington, C.A., M. Hinton, G.R. Person and I.J. Chopra, 1991. Organic acids as microorganisms decontaminators. J. Applied Bacteriol., 70: 156-172.

55. Leistner, L., 2000. Basic aspects of food preservation by Hurdle Technology. Int. J. Food Microbiol., 55: 181-186.

56. Sorrells, K.M., 1989. Effect of $\mathrm{pH}$ acidulant, time and temperature on the growth of Listeria monocytogenes. J. Food Prot., 52: 571-573.

57. Anonymous, M., 1990. Acidulants: Ingredients that do more than meet the acid test. J. Food Technol., 44: 76-83.

58. Buchanan, R.L. and M.A. Golden, 1994. Interaction of citric acid concentration and $\mathrm{pH}$ on the kinetics of Listeria monocytogenes inactivation. J. Food Prot., 57: 567-570.

59. Young, K.M. and P.M. Foegeding, 1993. Acetic, lactic and citric acids and $\mathrm{pH}$ inhibition of Listeria monocytogenes Scott A and the effect on intracellular pH. J. Applied Bacteriol., 74: 515-520.

60. Jay, J.M., 1992. Intrinsic and Extrinsic Parameters of Food that Affect Microbial Growth. In: Modern Food Microbiology, Jay, J.M. (Ed.). vi Book, New York, pp: 38-62.

61. Conner, D.E., J.S. Kotrola, W.B. Mikel and K.C. Tamplyn, 1997. Effect of acetic acid-Lactic acid treatment applied to beef I rim on population of Escherichia coli 0157: H7 and listeria monocytogenes in ground beef. J. Food Prot., 60: 1560-1565.

62. Cutter, C.N., W.J. Dorsa and G.R. Siragusa, 1997. Parameters affecting the efficacy of spray washes against Escherichia coli O157: $\mathrm{H7}$ and fecal contamination. J. Food Prot., 60: 614-618.

63. Bell, F.M., T.R. Marshall and E.M. Anderson, 1986. Microbiological and sensory tests of beef treated with acetic and formic acids. J. Food Prot., 49: 207-210.

64. Kochevar, S.L, J.N. Sofos, S.B. LeValley and G.C. Smith, 1997. Effect of water temperature, pressure and chemical solution of removal of fecal material and bacteria from lamb adipose tissue by spray-washing. J. Meat Sci., 45: 377-388.
65. Mikel, W.B., B.L. Goddard and D.D. Bradford, 1996. Muscle microstructure and sensory attributes of organic acid treated beef strip loins. J. Food Sci., 61: 1058-1061.

66. Anderson, M.E. and R.T. Marshall, 1990. Reducing microbial populations on beef tissues: Concentration and temperature of an acid mixture. J. Food Sci., 55: 903-905.

67. Koos, I.J.T. de, 1992. Lactic acid and lactates. Preservation of food products with natural ingredients. J. Food Market. Technol., 6: 5-11.

68. Rosmini, M.R., F. Perlo, J.A. Pérez-Alvarez, M.J. Pagán-Moreno, A. Gago-Gago, F. LópezSantoveòa and V. Aranda-Catalé1, 1996. TBA test by an extractive method applied to pâté. J. Meat Sci., 42: 103-110.

69. Shelef, L.A., 1994. Antimicrobial effects of sodium lactate and other additives in a cooked ham product on sensory quality and development of a strain of Lactobacillus curvatus and Listeria monocytogenes. Int. J. Food Microbiol., 66: 197-203.

70. Miller, R.K. and G.R. Acuff, 1994. Sodium lactate affects pathogens in cooked beef. J. Food Sci., 59: 15-19.

71. Bedie, G.K., J. Samelis, J.N. Sofos, K.E. Belk, J.A. Scanga and G.C. Smith, 2001. Antimicrobials in the formulation to control Listeria monocytogenes postprocessing contamination on frankfurters stored at $4{ }^{\circ} \mathrm{C}$ in vacuum packages. $\mathrm{J}$. Food Protect., 64: 1949-1955.

72. Mbandi, E. and L.A. Shelef, 2002. Enhanced antimicrobial effects of combination of lactate and diacetate on Listeria monocytogenes and Salmonella spp. in beef bologna. Int. J. Food Microbiol., 76: 191-198.

73. Friedrich, L., I. Siró, I. Dalmadi, K. Horváth, R. Ágoston and Cs. Balla, 2008. Influence of various preservatives on the quality of minced beef under modified atmosphere at chilled storage. J. Meat Sci., 79: 332-343.

74. Barmpalia, I.M., K.P. Koutsoumanis, I. Geornaras, K.E. Belk, J.A. Scanga, P.A. Kendall, G.C. Smith and J.N. Sofos, 2005. Effect of antimicrobials as ingredients of pork for Lesteria monocytogenes control during storage at 4 or $10^{\circ} \mathrm{C}$. J. Food Microbiol., 22: 205-211.

75. Diez, A.M., E.M. Santos, I. Jaime and J. Rovira, 2008. Application of organic acid salts and highpressure treatments to improve the preservation of blood sausage. J. Food Microbiol., 25: 154-161. 
76. Jo, S.C., A.R. Rim, H.J. Park, H.G. Yuk and S.C. Lee, 2006.Combined treatment with silver ions and organic acid enhances growth-inhibition of Escherichia coli O157: H7. J. Food Control, 18: $1235-1240$.

77. FSIS-USDA, 1996. Pathogen reduction, Hazard Analysis and Critical Control Point (HACCP) systems: Final rule. Federal Register, 61: 38805-38989.

78. FSIS-USDA. 1995. Comparison of methods for achieving the zero tolerance standard for fecal, ingesta and milk contamination of beef carcasses. Notice of conference. Federal Register, 60: 49553-49564.

79. FSIS-USDA. 1996. Achieving the zero tolerance performance standard for beef carcasses by knife trimming and vacuuming with hot water and steam. Use of acceptable carcass interventions for reducing carcass contamination without prior agency approval. Notice of Policy Change. Federal Register, 61: 15024-15027.
80. Hardin, M.D., G.R. Acuff, L.M. Lucia, J.S. Oman and J.W. Savell, 1995. Comparison of methods for decontamination from beef carcass surfaces. J. Food Prot., 58: 368-374.

81. Reagan, J.O., G.R. Acuff, D.R. Buege, M.J. Buyck, J.S. Dickson, C.L. Kastner, Marsden, J.L. Morgan, J.B.R. Nickelson, G.C. Smith and J.N. Sofos. 1996. Trimming and washing of beef carcasses as a method of improving the microbiological quality of meat. J. Food Prot., 59: 751-756. 